"Does having knowledge of green human resource management practices influence its implementation within organizations?"

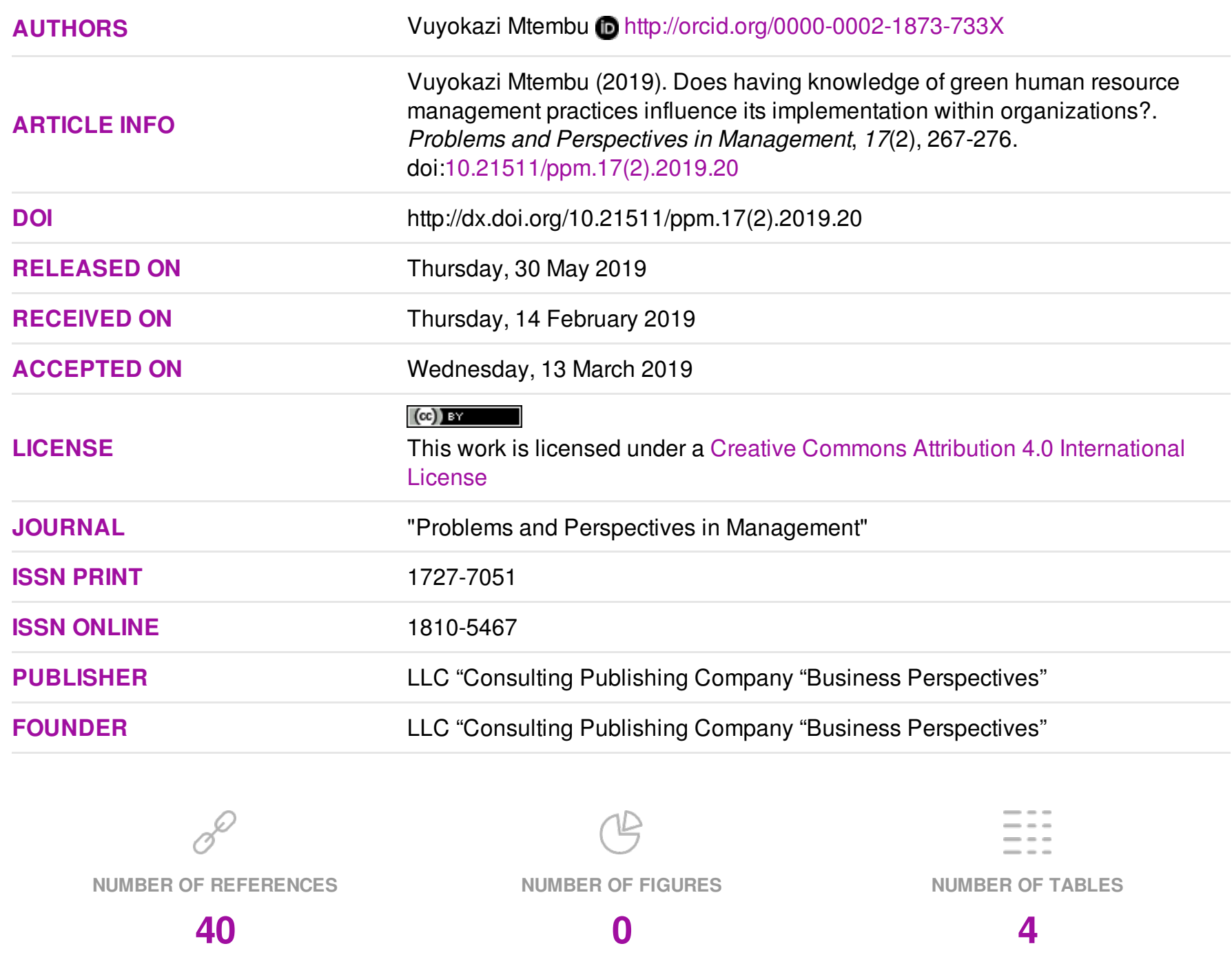

(C) The author(s) 2022. This publication is an open access article. 


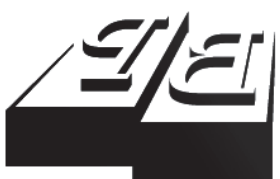

BUSINESS PERSPECTIVES

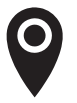

LLC "CPC "Business Perspectives" Hryhorii Skovoroda lane, 10, Sumy, 40022, Ukraine

www.businessperspectives.org

Received on: $14^{\text {th }}$ of February, 2019 Accepted on: $13^{\text {th }}$ of March, 2019

(C) Vuyokazi Mtembu, 2019

Vuyokazi Mtembu, Doctor, Lecturer, Graduate School of Business and Leadership, University of KwaZuluNatal, South Africa.

\section{DOES HAVING KNOWLEDGE OF GREEN HUMAN RESOURCE MANAGEMENT PRACTICES INFLUENCE ITS IMPLEMENTATION WITHIN ORGANIZATIONS?}

\begin{abstract}
Sustainability and green practices are in the frontline of issues organizations globally are concerned about because of the consequences of climate change and its challenges. The objective and key question of this study was to determine whether there is a relationship between knowledge of green human resource management (HRM) practices and its implementation within the organizations. The study followed a methodology of triangulated empirical research approach with a combined method of qualitative and quantitative research approaches. Human resource practitioners from human resource divisions in higher education institutions in KwaZulu-Natal, South Africa, formed the population surveyed. Interview schedule and questionnaires were instruments used in data collection. Thematic analysis was used to analyze data collected from interviews. Statistical Package for Social Sciences (SPSS) version 24 was used to analyze quantitative data collected. About half of HR practitioners indicated minimal awareness of the concept 'green HRM', but reflected moderate knowledge and understanding of green HRM activities. Overall, the findings revealed a moderate application of green HRM principles in HRM activities in the institutions. There was no policy framework in the form of green HRM policies to drive green activities within the HR divisions and institutionally. Findings also revealed that there is a relationship between knowledge of green HRM activities and its implementation within the organization. Also, a strong correlation was found to exist between green HRM policies and implementation of green HRM activities in the organization. This then led the researcher to recommend that organizations who aspire to go green, be resource efficient and sustainable will need to have green HRM policies in place, they will also need to ensure that training and awareness workshops on green HRM are conducted to skill and equip all stakeholders involved.
\end{abstract}

\section{Keywords}

human resource management, knowledge management, sustainable organizations, green human resource management

\section{JEL Classification J24}

\section{INTRODUCTION}

Knowledge is power, information is liberating, and education is the prerequisite of progress in every society and in every family.

Kofi Anan (1938-2018)

Mandip (2012, p. 244) explains green human resource management as "the use of human resource policies to promote sustainable use of resources within business organizations and, more generally to promote the cause of environmental sustainability". A number of studies have been done in green HRM and its role in organizations with recent studies, including those of Haddock-Millar, Sanyal, and Müller-Camen (2016), Renwick, Jabbour, Muller-Camen, Redman, and Wilkinson (2016), Ahmad (2015), Opatha and Arulrajah (2014), 
Prasad (2013), Mandip (2012). This article aims to contribute in the green HRM research by assessing whether there is a relationship between having knowledge of green HRM practices and its implementation within the organizations. Furthermore, the study extends the body of knowledge in green HRM chronicle by focusing on green HRM practices under the unique South African and African conditions of work and business operations, which have different priorities in many aspects when compared to priorities in the developed economies. These differences include amongst other things work culture, economic and social priorities. Ulrich's (1997) HR role model and Senge's organizational learning model (1990) will form a theoretical base that underpins and guides the discussion in this article. This article interrogates the question: is there a relationship between having knowledge of green HRM practices and its implementation within the organizations.

\section{LITERATURE REVIEW}

\subsection{Knowledge}

There is no universal definition of what is knowledge, but it is often explained by distinguishing between explicit and tacit knowledge. Explicit knowledge can be codified, recorded and can be held in databases, corporate intranets and intellectual property portfolios. Tacit knowledge exists in the minds of people, it is difficult to articulate in writing and it is acquired by means of personal experience (Nonaka \&Takeuchi, 1995, cited in Armstrong, 2016). Knowledge can be held in databanks. It can also be found in presentations, reports, libraries, policy documents and manuals. It can be moved around the organization via information systems and routine methods, namely meetings, workshops, courses, master classes, written publications, emails, disks and social media (Armstrong, 2016).

In this century of globalization and rapid innovation, economic, social, technological and political changes, for companies to survive they need to keep up to date with new information and trends in their respective sectors. In doing so they need to embrace knowledge management as one of the main sources of competitive edge. The most important knowledge resides in human resources. Organizations need to make sure that they tap into that wealth of knowledge and wisdom and make sure that it is shared within the organization and used optimally for the benefit of the business and its stakeholders.

\subsection{HR roles and practices in organizations}

Ulrich's HR role model (1997) consists of a set of proactive roles divided into two directions: strat- egy versus operations, and process versus people (Francis \& Keegan, 2006). A strategic partner, an administrative expert, an employee champion and a change agent are four key roles that emerge (Ulrich, 1997). The role of a strategic partner lies in the partnership of the HR professionals with line managers to help them achieve their goals via effective strategy formulation and strategy execution (Ulrich \& Brockbank, 2005, cited in Francis \& Keegan, 2006). Explaining the other three roles meticulously, Francis and Keegan (2006) explain that the agents of change are in charge of the delivery of organizational transformation and culture change, administrative staff constantly improves organizational efficiency by readjustment of the HR function and other work processes such as introducing 'shared services'. One more highly important role is that of employee champion. This is a particularly interesting role, since it joins a focus on people and a focus on day-to-day operational issues together (Francis \& Keegan, 2006). Haddock-Millar, Sanyal, and Müller-Camen (2016) cited that in matters relating to sustainability in the organizations, the problem is the lack of readiness from the HR to maintain sustainability at a strategic level. Personnel managers may not consider themselves strategic drivers of initiatives on environmental protection and sustainable development; instead, they mostly perceive themselves as ideal partners for the transfer of values to encourage behavioral change after developing a strategy outside of HR (Haddock-Millar, Sanyal, \& Müller-Camen, 2016).

In the strategic role, $\mathrm{HR}$ as members of the executive team should be fully-fledged strategic partners and must impel and guide serious discussions on how the company should be organized to take on its strategy role (Ulrich, 1997). This should include 
the 'greening' strategy. Change happens, whether organizations like it or not change is inevitable. The pace of change is fast and sometimes change is unexpected. There is change in climate, change in technology, change in the economy and change in lifestyles. Change is constant in issues that have an effect on employees and the organization. With so much change-taking place, the implication is that HR practitioners can no longer afford to be complacent and focus only on the traditional roles of HR. HR should adjust, adapt and evolve with the times in order to continue delivering value, productivity and profitability to the organization. Ulrich (1998) emphasizes that HR roles should be aligned with the changes, so that HR cannot only be determined by what it does in the organization, but be defined by what it delivers, the results that enhance the organization's value to customers, investors and employees. HR professionals should manage change and transformation in the organization. Ulrich continues to suggest that, as change agents, HR professionals do not need to execute change themselves, but their major role is to make sure that change is carried out effectively and on time (Ulrich, 1998). The human resource division is the most important change agent in any institution. Studies have shown that human resources can play a vital role in assisting organizations to change and achieve sustainability (Jabbour \& Santos, 2008; Liebowitz, 2010; Prasad, 2013).

As administrative experts, efficiency will need to be improved, with a vast number of HR processes performed daily, processes will need to be faster, better, smarter and cheaper (Ulrich, 2008). Some HR practices are implemented through administrative processes, such as technology, and others via policies, procedures and other administrative measures. In adopting green practices, HR will therefore need to minimize unnecessary and inefficient paper use, daunting procedures and processes, red tape and bureaucracy. The future of a green and sustainable HR division is in the adoption of new, cost-effective and efficient administration processes. This means using faster cost efficient technology in the performance of daily activities, such as the e-HR, systems, including e-recruitment using an online application system and Skype interviews for candidates who are further away from the institution. Online interactive electronic performance management systems, virtual training and self-administered computer training systems are all as part of e-HR towards the efforts of greening and saving resources.

Employee championing means equipping and empowering employees with knowledge and skills on green processes. Ulrich in his latest modification of roles emphasizes that being an employee champion also means being a human capital developer (Ulrich \& Brockbank, 2005). In the process of providing knowledge to employees, HR practitioners will need to ensure effective knowledge management, that is the process of effectively creating, sharing, using and managing an organization's knowledge and information (Girard \& Girard, 2015, cited in Armstrong, 2016). In this role, HR practitioners are accountable for ensuring that employee engagement and full commitment to the organization's success is realized. They must ensure that the employment contract is not merely transactional, but relational and all parties to the contract are content (Ulrich, 1998). In this role, the employer-employee relationship that is healthy and productive is key. The HR division should make sure that they are getting commitment and buy-in from employees and all relevant stakeholders to carry out green projects in the organization. Mandip (2012) clarifies the role of HR executives here by stating that, in educating and bringing awareness to staff on green concerns, a crucial role for HR environmental executives could be to guide line managers as to achieving full staff co-operation in implementing environmental policies. This means that HR should educate supporters and create networks of problem solvers, ready to act to change the status quo. This can happen only when the company establishes formal and informal communication with its employees, which emphasizes the company's green efforts, for example, in the company newsletter and on the website (Mandip, 2012).

\subsection{Organizational learning and knowledge management in $\mathrm{HR}$}

Peter Senge (1990), one of the 'fathers' of organizational learning, specifies learning organizations as "organizations where people continually expand their capacity to create the results they truly desire, where new and expansive patterns of thinking are nurtured, where collective aspiration is set free, and where people are continually learning to see the whole together" 
(Senge, 1990, p. 3). Senge's organizational learning model has five disciplines that develop a learning organization, namely shared vision, personal mastery, systems thinking, mental models and team learning (Senge, 1990).

Out of the five disciplines, for the purpose of this study, only two disciplines will be looked at, and those are shared vision and team learning. A shared vision is a discipline for reconciling the vision and efforts of people across the organization. "The principle of shared vision leverages the most productive usage of capital, technology, and human capital since resources are coordinated toward the same ends. Processes, job functions, system-wide problem-solving, and so forth, flow in a common direction" (Senge, 1990 cited in Raines, 2009). This then means that to achieve a green and sustainable organization, HR executives and the organization's leadership should in a consultative process with employees craft a vision of environmental stewardship, and share that vision with all stakeholders and importantly with employees. Leaders should be proud vision bearers. They should sell the vision to employees, and encourage employees to embrace and follow up on that vision and lead by example. Shared vision on environmental efficiency will have employees effortlessly and willingly initiating and driving environmental efficiency projects within the organization, which is the great result of an effectively shared vision.

Team learning and teamwork are essential for a successful environmental management system within the organization (Daily \& Huang, 2001). When there is team earning, there is a flow of information, feedback freely given and eagerly accepted and valued, generative thinking, and innovative problem-solving (Raines, 2009). Raines (2009) continues to suggest more benefits of team learning by stating that, in a more in-depth dialog, people learn to ask questions that help learning instead of individuals who make expert assessments. There is awareness of the richness that occurs when people feel confident in what they really think, how they really feel, what they really want for themselves and their organization (Raines, 2009). People learn how to inquire genuinely, carefully, and to clearly advocate with balanced and suitable substantiating data (Senge, 1990, cited in Raines, 2009). To achieve sustainability in the organizations, there must be free sharing of information, ideas and opinions.
Leadership and management should adopt an opendoor policy where teams and individual employees are afforded a space and opportunity to voice their opinions on how the organization can be transformed into a green, environmental-friendly and efficient organization. Teams should be allowed time and platforms to meet, creatively conceptualize greening ideas and share those ideas in spaces without fear or favor. In doing so team learning will be enhanced, teamwork will benefit and green projects will thrive. To ensure a conducive space for team learning and teamwork, HR should play a role of being facilitators of learning, and attempt to promote respect for one another between members and there is respect for each member's opinions and ideas. A team effort towards building a green and environmentally efficient institution will then be achieved. "The creation of structures and opportunities for technical, action, and social learning thus has the potential to transform individual learning about sustainability into organizational learning" (Hugh \& Talwar, 2010, p. 387). Nowadays, changes occur very quickly. Organizations are constantly trying to adapt to new technologies, climate change, information changes, socio-economic and product change. Creating a learning organization, where do we start? Breda-Verduijn and Heijboer (2016) suggest that breeding a learning organization begins with values related to the learning culture of the organization. It is important to realize the values set forth in the vision of learning, as well as the mission the organization. In addition, they argue that a powerful learning culture is an effective continuous learning environment, employees need the skills and flexibility to handle current changes in their work and continuing education (Breda-Verduijn and Heijboer, 2016). The institution's vision, mission, values, and policies should all incorporate clauses on the importance of learning to achieve a green, sustainable learning.

An investment in knowledge pays the best interest.

Benjamin Franklin (1706-1790)

\section{METHODOLOGY}

The study followed a methodology of triangulated empirical research approach with a combined method of qualitative and quantitative research approaches. Triangulation means that research is approached from multiple perspectives (Sekaran 
\& Bougie, 2013). Human resource practitioners from three institutions of higher learning in KwaZulu-Natal, South Africa, formed the population surveyed. Twenty senior HR practitioners and managers who were strategically placed within the HR division were interviewed. Self-administered questionnaires were used to collect quantitative data. Sixty questionnaires were distributed; fifty-three came back, which is a response rate of eighty-eight per cent. Five-point Likert scale type questions were used in the questionnaire that collected quantitative data. Interview schedule was used to collect qualitative data. A thematic analysis was used to analyze data collected from the interview. Quantitatively, Statistical Package for Social Sciences (SPSS) version 24 was used to analyze data collected. Qualitative data collected was analyzed using thematic analysis, while descriptive analysis and inferential analysis in form of Spearman's ranking test was used to analyze and interpret quantitative data.

\section{RESULTS}

\subsection{Presentation and discussion of results from qualitative study}

The following themes emerged from the interviews:

\subsubsection{Minimal awareness of the concept 'green HRM', moderate knowledge and understanding of green HRM activities}

Half of HR practitioners interviewed in the study indicated minimal awareness of the concept 'green HRM', but reflected moderate knowledge and understanding of green HRM activities. This means they had some knowledge of what needs to be done to ensure that HR operations are resource efficient and sustainable, but they were not aware that there is special term or concept called 'green HRM'. These results are in line with the research conducted in India by Sakhawalkar and Thadani (2013) who have analyzed green HR practices and the responsiveness among IT sector employees in Pune Region, India. The results of the study showed that people who do not know about the term 'green HR' know about the practices and know that their organization adheres to them (Sakhawalkar \& Thadani, 2013). The study also revealed that one of the reasons HR practitioners were not fully aware of the concept 'green HRM' was because of the fact that in the institutions surveyed, there were no green HRM policies that talk to greening of HR in the organization, there were only general environmental policies, which are also not communicated effectively across organizational divisions. These findings correlate with findings of a UK study by Harris and Crane (2002), which revealed that while most executives and employees may be aware of green pressures, only few organizations are responding to the expected level of enthusiasm. Harris and Crane (2002) also found that macro-environmental pressures on the organization were currently insufficient to require anything more than superficial policy statement. In this study, in three surveyed universities, HR practitioners were not aware of these environmental policies in their institution, which is an alarming factor, since it indicates certain level of ignorance or lack of learning culture within the HR department. In addition, lack of top management commitment to greening proved to be a huge contributor in this problem as revealed in the study. This again corresponds to Harris and Crane (2002) study, which revealed that managers show somewhat apathetic attitude to green issues in many organizations, resulting in evidence of significant gaps between the company's position and actual practice.

\subsubsection{Moderate implementation of green HR activities}

The majority of participants mentioned that HR divisions in their institutions played a minimal to moderate role towards greening efforts in the institution. Findings revealed that there were few green conscious activities applied by HR, mainly in recruitment and performance management systems. Some of green HR activities participants mentioned as utilized the institution surveyed include adopting green and resource-efficient activities through online recruitment of staff, Skype interviews for far away candidates, video conferencing of meetings, doing performance evaluations online and sharing organizational policies on an online platform as well. Regarding engagement of employees on greening issues, incorporating green activities in key performance areas (KPA's) training, and on compensation, results showed that nothing was done by the institutions surveyed on 
these activities to incorporate 'green HRM' principle. The Greening of HR Survey conducted by Buck Consultants, during a survey of 93 US firms, showed that 54 per cent of respondents included environmental management into their business transactions (Buck, 2009). The research also shows that joint green human resources initiatives include the use of web- or teleconferencing to reduce travel (78 percent), promoting paperless use (76 percent), and implementing health improvement programs to ensure employees' proper nutrition, fitness, and healthy lifestyle (68 percent) (Buck, 2009). These are some of the greening activities within the scope of HR division and that the division can deliver in their organizations. As much as the institutions surveyed in this study attempt some of these initiatives as stated in Buck (2009), the level at which these are done is very minimal. A lot of research still needs to be performed to achieve full commitment to greening from these institutions. In the study that surveyed $147 \mathrm{UK}$ firms, respondents rated internal awareness raising campaigns, senior leadership appearances and green champions or green teams as the most effective ways to promote pro-environmental behavior (Zibarras \& Ballinger, 2011, cited in Bartlett, 2011).

\subsubsection{There are no HR-driven environmental education and awareness campaigns}

Asked if are there any education and awareness campaigns on greening and using resources efficiently conducted by the HR division in the institutions, the majority of practitioners disagreed, meaning that $\mathrm{HR}$ is not involved in any education and awareness campaigns that promote green initiatives within the organization. This should be a concern to the advocates of green HRM, as education and awareness play a major role in changing people's attitudes and behaviors. The sentiment shared by HR practitioners in interviews was that 'greening issues are not the priority and responsibility of HR', which is one of the major reasons for HR division resisting involvement in greening campaigns and programs. This finding is consistent with many studies that found that the HR division does not see greening of the organization as part of their responsibilities or mandate (Mtembu, 2018; Liebowitz, 2010; Jabbour \& Santos, 2008; Daily \& Huang, 2001).

\subsection{Presentation and discussion of results from quantitative study}

\subsubsection{Descriptive statistics}

\subsubsection{Knowledge of green HRM practices}

Asked if they are aware of the concept 'green HRM' and what its practices entail, as indicated in Table 1, the modal response here was 'Agree', with 45 percent of the respondents agreeing that they do have some moderate knowledge of 'green HRM' practices, 15 percent strongly agreed that they do fully understand 'green HRM' concept and have knowledge of 'green HRM' practices. This then means that about 60 percent of the respondents had some knowledge and understanding of the concept, 21 percent of the respondents indicated that they have no understanding of the concept 'green HRM'. In Table 1 the mean average is 3.42 , which indicates that more than half of respondents agreed that they understand and have knowledge of 'green HRM' with a modal (mode) response of 4 which is 'Agree'. These results are in line with the findings of the Indian study, according to which slightly less than half of employees surveyed do not know about 'green HRM', while the remaining employees has some moderate awareness and knowledge of green HRM (Sarode, J. Patil, \& D. Patil, 2016).

Table 1. Knowledge of green HRM practices

\begin{tabular}{|c|c|c|c|}
\hline \multicolumn{2}{|c|}{ Response } & Frequency & Percent \\
\hline \multicolumn{2}{|c|}{ Strongly disagree } & 7 & 13.2 \\
\hline \multicolumn{2}{|l|}{ Disagree } & 4 & 7.5 \\
\hline \multicolumn{2}{|l|}{ Uncertain } & 10 & 18.9 \\
\hline \multicolumn{2}{|l|}{ Agree } & 24 & 45.3 \\
\hline \multicolumn{2}{|c|}{ Strongly agree } & 8 & 15.1 \\
\hline \multicolumn{2}{|l|}{ Total } & 53 & 100.0 \\
\hline Mean & Median & Mode & Std. deviation \\
\hline 3.42 & 4.00 & 4 & 1.232 \\
\hline
\end{tabular}

\subsubsection{Implementation of green HRM practices}

Asked whether in their daily activities greening principles are being practiced, Table 2 shows that 45 per cent agreed and 15 percent strongly agreed, 
bringing the number of those who agreed to 60 percent. Table 2 also reflects a mean of 3.26 , which indicates that more than the average number of respondents agreed that green processes are incorporated into their daily activities. The modal response was four, which means that most of the respondents 'agreed' that there was a certain implementation of green principles in their personnel activities. Evidence from previous studies states that companies that incorporate green practices have a greater potential to attract high talent and good quality candidates who are also green-conscious (Wehrmeyer, 1996; Stringer, 2009, cited in Jackson et al., 2011; Grolleau, Mzoughi, \& Pekovic, 2012). Other studies also found evidence that green conscious companies are perceived with a good image and yield cost efficiency benefits (Gupta, 2016; Aqayo, 2008; Smith \& Rupp, 2004; Haddas, 2004; Chapman \& Webster, 2003).

Table 2. Implementation of green HRM practices

\begin{tabular}{c|c|c|c} 
& & \multicolumn{3}{c}{ Source: Present study. } \\
\hline Response & Frequency & Percent & $\begin{array}{c}\text { Valid } \\
\text { percent }\end{array}$ \\
\hline Strongly disagree & 8 & 15.1 & 15.1 \\
\hline Disagree & 10 & 18.9 & 18.9 \\
\hline Uncertain & 3 & 5.7 & 5.7 \\
\hline Agree & 24 & 45.3 & 45.3 \\
\hline Strongly agree & 8 & 15.1 & 15.1 \\
\hline Total & 53 & 100.0 & 100.0 \\
\hline Mean & Median & Mode & $\begin{array}{c}\text { Std. } \\
\text { deviation }\end{array}$ \\
\hline 3.26 & 4.00 & 4 & 1.347 \\
\hline
\end{tabular}

\subsection{Inferential statistics}

\subsubsection{Spearman's correlation}

The Spearman's rank order correlation is a nonparametric version of the Pearson product moment correlation. The Spearman correlation coefficient ( $\rho$, also signified by $r s$ ) measures the strength and association direction between two ranged variables (statistics.laerd.com). Spearman's correlation is one of the variables that is used to examine relationships between two ordinal variables (Sekaran \& Bougie, 2013). Spearman's correlation was used in this study to examine if there is any relationship between HR employees' knowledge of green HRM and the way green HRM practices are implemented in daily HR activities. The correlation coefficient is a generalizing type of number that varies in value from +1.0 , which means a perfect positive correlation/relationship, to -1.0 , which means a perfect negative correlation/relationship. From the actual figure computed, one deduces whether there is a negative or positive correlation between the variables. A coefficient ( $r$ value) between 0.10 and 0.29 or -0.10 and -0.29 indicates a weak correlation; if it is between 0.30 and 0.49 or -0.30 and -0.49 , it indicates a moderate correlation, and if a coefficient falls between 0.50 and 1.0 or -0.50 and -1.0 , it indicates a strong correlation. A coefficient close to zero indicates no relationship at all (Ferreira, 2000).

\subsubsection{Spearman's correlation: relationship between green HRM knowledge and its implementation in the organization}

The following hypotheses were investigated:

H0: There is no relationship between having knowledge of green HRM practices and its implementation within organizations.

Ha: There is a relationship between having knowledge of green HRM practices and its implementation within organizations

In determining if there is any form of association between knowledge of green HRM and implementation of green HRM activities in the organization, the results in Table 3 indicate that there is a strong correlation or simply a significant relationship between knowledge of green HRM practices $(r=-.079)$ and implementation of green HR activities in the organization $(r=1.000)$. This then confirms that knowledge of green HRM does have a significant influence in application and implementation of green HR activities. Therefore, this means:

Reject - the null hypothesis H0: There is no relationship between having knowledge of green HRM practices and its implementation within organizations.

Accept - the alternative hypothesis Ha: There is a relationship between having knowledge of green HRM practices and its implementation within organizations. 
Table 3. Spearman's correlation: knowledge of green HRM practices and implementation of green HRM practices.

Source: Present study.

\begin{tabular}{|c|c|c|c|c|}
\hline \multicolumn{3}{|c|}{ Correlations } & \multirow{2}{*}{$\begin{array}{c}\begin{array}{c}\text { Knowledge of } \\
\text { green HRM }\end{array} \\
1.000\end{array}$} & \multirow{2}{*}{$\begin{array}{c}\begin{array}{c}\text { Implementation } \\
\text { of green HRM }\end{array} \\
-.079\end{array}$} \\
\hline \multirow{6}{*}{ Spearman's rho } & \multirow{3}{*}{$\begin{array}{l}\text { Knowledge of green HRM } \\
\text { practices }\end{array}$} & Correlation coefficient & & \\
\hline & & Sig. (2-tailed) & 0. & .572 \\
\hline & & $\mathrm{N}$ & 53 & 53 \\
\hline & \multirow{3}{*}{$\begin{array}{l}\text { Implementation of green HRM } \\
\text { practices }\end{array}$} & Correlation coefficient & -.079 & 1.000 \\
\hline & & Sig. (2-tailed) & .572 & 0. \\
\hline & & $\mathrm{N}$ & 53 & 53 \\
\hline
\end{tabular}

\subsubsection{Spearman's correlation: relationship between green HRM knowledge and availability of green HRM policies in the organization}

The following hypotheses were investigated:

HO: There is no relationship between having green HR policies and green HRM implementation within organizations.

$\mathrm{Ha}: \quad$ There is a relationship between having green HRM policies and green HRM implementation within organizations.

In determining if there is any form of association between knowledge of green HRM and availability of green policies in the HR division, results in Table 4 indicate that there is a perfect strong correlation between availability of green policies in the HR division $(r=.301)$ and knowledge of green HRM practices $(r=1.000)$. This then informs us that the existence of green policies is important to inform employees on greening principles and practices expected from them. This result again confirms and is consistent with the results found in the qualitative results of this study where man- agers that were interviewed mentioned that policies are a very important guideline and information tools that guide operations and practices that should be followed in performing one's job on a daily basis. Therefore, this means:

Reject - the null hypothesis H0: There is no relationship between having green $H R$ policies and green HRM implementation within organizations.

Accept - the alternative hypothesis Ha: There is a relationship between having green HRM policies and green HRM implementation within organizations.

\section{SUMMARY OF FINDINGS}

About half of HR practitioners indicated minimal awareness of the concept green HRM, but reflected moderate knowledge and understanding of green HRM activities. Overall, the findings revealed a moderate application of green HRM principles in HRM activities in the institutions. There was no policy framework in the form of green HRM policies to drive green activities within the HR division and institutionally. Findings also revealed that there is a relationship

Table 4. Spearman's correlation: knowledge of green HRM practices and green policies

Source: Present study.

\begin{tabular}{|c|c|c|c|c|}
\hline \multicolumn{3}{|c|}{ Correlations } & \multirow{2}{*}{$\begin{array}{c}\text { Knowledge of green } \\
\text { HRM practices }\end{array}$} & \multirow{2}{*}{$\begin{array}{c}\begin{array}{c}\text { Green policies in } \\
\text { HR division }\end{array} \\
301^{*}\end{array}$} \\
\hline \multirow{6}{*}{ Spearman's rho } & \multirow{3}{*}{ Knowledge of green HRM } & Correlation coefficient & & \\
\hline & & Sig. (2-tailed) & 0. & .030 \\
\hline & & $\mathrm{N}$ & 53 & 52 \\
\hline & \multirow{3}{*}{$\begin{array}{l}\text { Green policies in HR } \\
\text { division }\end{array}$} & Correlation coefficient & $.301 *$ & 1.000 \\
\hline & & Sig. (2-tailed) & .030 & 0. \\
\hline & & $\mathrm{N}$ & 52 & 52 \\
\hline
\end{tabular}


between knowledge of green HRM activities and its implementation within the organization. Also a strong correlation was found to exist between having green HRM policies and implementation of green HRM activities in the organization. This then led the researcher to recommend that organ- izations who aspire to go green, be resource-efficient and sustainable will require green HRM policies as foundational policies in place and ensure that training and awareness workshops on green HRM are conducted to skill and equip all stakeholders involved.

\section{CONCLUSION}

This study was interested in finding out whether there is any relationship between the availability of green HRM policies and the knowledge of green HRM and how it is implemented in the organization. Findings confirmed that having some green HRM policies and some knowledge can have an influence on the implementation of green HRM activities within organizations. The study also indicated that for companies to achieve their green goals, the following should take place; greening requires a strategic commitment from the top echelons of the organizations to the bottom levels of the same. All staff members from entry up to exit should be provided with knowledge of greening, training and incentives for all those involved in green initiatives at an institution. Lastly, it is recommended that organizations should preach and practice the universal slogan of the three R's - Reduce, Reuse and Recycle.

\section{REFERENCES}

1. Ahmad, S. (2015). Green Human Resource Management: Policies and Practices. Cogent Business and Management, 2, 1-13. https://doi.org /10.1080/23311975.2015.1030817

2. Armstrong, A. (2016). Armstrong's Handbook of Strategic Human Resource Management (6th ed.). Kogan Page Publishers.

3. Breda-Verduijn, H., \& Heijboer, M. (2016). Learning culture, continuous learning, organizational learning anthropologist. Industrial and Commercial Training, 48(3), 123-128. https://doi.org/10.1108/ ICT-11-2015-0074

4. Buck Consultants. (2009). The Greening of HR Survey Results.

5. CIPD/KPMG UK, (2007). Labor Market Outlook: Quarterly Survey Report. Autumn, 2007.

6. Cohen, E., Taylor, S., \& MullerCamen, M. (2012). HRM's Role in Corporate Social and Environmental Sustainability. Virginia: SHRM Foundation.

7. Daily, B., \& Huang, S. (2001). Achieving Sustainability through attention to human resource factors in environment management. International Journal of Operations and Production Management, 21(12), 1539-1552. https://doi org/10.1108/01443570110410892
8. Dutta, S. (2012). Greening People: A Strategic Dimension. ZENITH International Journal of Business Economics and Management Research, 2(2), 143-148. Retrieved from http://zenithresearch.org. in/images/stories/pdf/2012/Feb/ ZIJBEMR/11 ZIJBEMR VOL2 ISSUE2_FEB2012.pdf

9. Francis, H., \& Keegan, A. (2006). The changing face of HRM: in search of balance. Human Resource Management Journal, 16(3), 231249. https://doi.org/10.1111/j.17488583.2006.00016.x

10. Grolleau, G., Mzoughi, N., \& Pekovic, S. (2012). Green not (only) for profit: An empirical examination of the effect of environmentalrelated standards on employee's recruitment. Resource and Energy Economics, 34(1), 74-92. Retrieved from https://ideas.repec.org/a/eee/ resene/v34y2012ilp74-92.html

11. Harris, L., \& Crane, A. (2002). The greening of organizational culture: Management views on the depth, degree and diffusion of change. Journal of Organizational Change Management, 15(3), 214-234. https://doi. org/10.1108/09534810210429273

12. Jabbour, C. J. C. (2011). How green are HRM practices, organizational culture, learning and teamwork? A Brazilian study. Industrial and Commercial Training, 43(2), 98-105. https://doi. org/10.1108/00197851111108926

13. Jabbour, C. J. C. (2015).

Environmental training and environmental maturity of Brazilian companies with ISO14001: Empirical evidence. Journal of Cleaner Production, 96(1), 331338. https://doi.org/10.1016/j. jclepro.2013.10.039

14. Jabbour, C. J. C., \& Santos, F. C. A. (2008). The Central role of Human Resources in search for Sustainable Organizations. International Journal of Human Resource Management, 19(12), 2133-2154. https://doi. org/10.1080/09585190802479389

15. Jackson, S. E., \& Seo, J. (2010). The greening of strategic HRM scholarship. Organization Management Journal, 7(4), 278-290. https://doi.org/10.1057/omj.2010.37

16. Jackson, S. E., Renwick, D., Jabbour, C. J., \& Muller-Camen, M. (2011). State-of-the-Art and Future Directions for Green Human Resource Management: Introduction to the Special Issue. Zeitschrift Fur Personalforschung, 25(2), 99-116. Retrieved from 
https://www.econstor.eu/bitstream/10419/71002/1/737597178. pdf

17. Leibowitz, J. (2010). The Role of HR in Achieving a Sustainability Culture. Journal of Sustainable Development, 3(4), 50-57. https:// doi.org/10.5539/jsd.v3n4p50

18. Mandip, G. (2012). Green HRM: People Management commitment to environmental sustainability. Research Journal of Recent Sciences, 1, 244-252. Retrieved from http:// www.isca.in/rjrs/archive/iscsi/38. ISCA-ISC-2011-18CLM-Com-03. pdf

19. Millar, C., Hind, P., \& Magala, S. (2012). Sustainability and the need for change: organizational change and transformational vision. Journal of Organizational Change Management, 25(4), 489-500. https://doi. org/10.1108/09534811211239272

20. Haddock-Millar, J., Sanyal, C., \& Müller-Camen, M. (2016). Green human resource management: a comparative qualitative case study of a United States multinational corporation. The International Journal of Human Resource Management, 27(2), 192-211. https://doi.org/10.1080/09585192.20 15.1052087

21. Miller, N., Pogue, D., Gough, Q., \& Davis, S. (2009). Green buildings and productivity. Journal of Sustainable Real Estate, 1(1), 65-89. Retrieved from http://www.josre. org/wp-content/uploads/2012/09/ Green_Buildings_ProductivityJOSRE_v1-41.pdf

22. Milliman, J., \& Clair, J. (1996). Best environmental HRM practices in the US. In W. Whremeyer (Ed.), Greening People: Human Resource and Environmental Management (pp. 49-74). Sheffield: Greenleaf Publishing. https://doi.org/10.9774/ GLEAF.978-1-909493-00-1_4

23. Mtembu, V. N. (2018). Greening is not a priority for human resource: Insights from human resource practitioners. Acta Commercii, 18(1), 1-8. https://doi.org/10.4102/ ac.v18i1.577

24. Muller-Christ, G., Sterling, S., van Dam-Mieras, R., Adomßent, M., Fischer, D., \& Rieckmann, M. (2014). The role of campus, curriculum, and community in higher education for sustainable development - a conference report. Journal of Cleaner Production, 62, 134-137. http://dx.doi.org/10.1016/j. jclepro.2013.02.029

25. Niu, D., Jiang, D., \& Li, F. (2010). Higher education for sustainable development in China. International Journal of Sustainability in Higher Education, 11(2), 153-162. https://doi. org/10.1108/14676371011031874

26. O’Donohuea, W., \& Torugsa, N. (2016). The moderating effect of 'Green' HRM on the association between proactive environmental management and financial performance in small firms. The International Journal of Human Resource Management, 27(2), 239261. https://doi.org/10.1080/095851 92.2015.1063078

27. Opatha, H., \& Arulrajah, A. (2014). Green Human Resource Management: Simplified General Reflections. International Business Research, 7(8), 101-112. https://doi. org/10.5539/ibr.v7n8p101

28. Paillé, P., Chen, Y., Boiral, O., \& Jin, J. (2014). The Impact of Human Resource Management on Environmental Performance: An Employee-Level Study. Journal of Business ethics, 121(3), 451-466. Retrieved from https:// www.academia.edu/5652674/ Paill\%C3\%A9_P._Chen_Y. Boiral_O._and_Jin_J._2014_.The_ Impact_of_Human_Resource_ Management_on_Environmental_Performance_an_EmployeeLevel_Study._Journal_of_Business_Ethics_121_3_451-466

29. Pinzone, M., Guerci, M., Lettieri, E., \& Redman, T. (2016). Progressing in the change journey towards sustainability in healthcare: the role of 'Green' HRM. Journal of Cleaner Production, 122, 201-211. Retrieved from https://pubag.nal.usda.gov/ catalog/5317450

30. Prasad, R. S. (2013). Green HRM-Partner in Sustainable Competitive Growth. Apeejay Journal of Management Sciences and Technology, 1(1), 15-18. Retrieved from https://apeejay.edu/aitsm/journal/docs/ajmst-010103oct13.pdf

31. Renwick, D., Jabbour, C. J. C., Müller-Camen, M., Redman,
T., \& Wilkinson, A. (2016). Contemporary developments in Green (environmental) HRM scholarship. The International Journal of Human Resource Management, 27(2), 114-128. https://doi.org/10.1080/09585192.20 15.1105844

32. Renwick, D., Redman, T., \& Maguire, S. (2008). Green HRM: A review, process model, and research agenda. Shefield: Sheffield University, UK.

33. Sakhawalkar, A., \& Thadani, A. (2013). The Study of Current Green HR Practices and the Responsiveness among the Employees of I.T. Sector in Pune Region. International Journal of Science and Research (IJSR), 4(1), 2324-2328. Retrieved from https://www.ijsr.net/archive/v4i1/ SUB15778.pdf

34. Sarode, A.P., Patil, J., \& Patil, D. T., (2016). A study of Green HRM and Its Evaluation with Existing HR Practices in Industries within Pune Region. International Journal of Research in Engineering, IT and Social Sciences, 6(4), 49-67.

35. Sekaran, U., \& Bougie, R. (2013). Business Research Methods. West Sussex, UK: John Wiley and Sons.

36. Senge, P. (1990). The fifth discipline: the art and practice of the learning organization. New York: Doubleday.

37. Shatouri, M., Omar, R., \& Igusa, K. (2012). Towards a New Era of Sustainability in the Automotive Industry: Strategic Human Resource Management and Green Technology Innovation. International Scholarly and Scientific Research \& Innovation, 6(9), 2364-2369.

38. Ulrich, D. (1998). A New Mandate for Human Resources. Harvard Business Review.

39. Ulrich, D., Younger, J., Brockbank, W., \& Ulrich, M. (2012). HR Talent and the New HR Competencies (RBL Whitepaper series). Retrieved from https://rbl-net.s3.amazonaws.com/ hrcs/2012/HRtalent-HRcompetencies.pdf

40. Wehrmeyer, W. (1996). Greening People: Human Resources and Environmental Management. Sheffield: Greenleaf Publishing. 